\title{
Control Strategy of a Matrix Converter with a Generator as Input
}

\author{
Junnosuke Haruna Student Member (Nagaoka University of Technology) \\ Jun-ichi Itoh Member (Nagaoka University of Technology)
}

Keywords: matrix converter, synchronous generator, synchronous reactance, input current stability control, optimal input power factor control

This paper describes a strategy for controlling the input current of a matrix converter with a generator as the input. The line impedance is larger than the power grid when the generator is used as the input of the matrix converter. The resonance between the synchronous reactance of the generator and the input capacitance results in unstable behavior of the matrix converter. For a stable operation, stability control is provided to the rotating frame on the generator side. With the proposed method, both generator current and output voltage can be controlled, regardless of the generator speed. In addition, optimal input power factor control is proposed for achieving the maximum modulation index of the matrix converter.

Fig. 1 shows the circuit diagram of a matrix converter with a generator as the input. The output impedance of the generator is very large because synchronous reactance dominants the input impedance. The synchronous reactance of the generator is substituted by the input filter reactance, because of which the system becomes unstable. To suppress the oscillations on the input side, a damping control for the generator is applied to the rotating frame.

Fig. 2 shows the block diagram of the stability control with an adaptive band-pass filter (BPF) in the d-q frame. The fundamental frequency component in the d-q frame then becomes a DC signal. In addition, harmonic components appear as ripples in the AC component. These harmonics components can be completely eliminated by using a low-pass filter (LPF), which has a long time constant. An advantage of the proposed method is that adjustment of the cut-off frequency in the LPF is independent of generator speed, as the fundamental frequency component of the input signal is converted to a DC signal in the rotating frame.

Fig. 3 shows the vector diagram when the input power factor is controlled for a given phase lag and phase lead. The terminal voltage depends on the input power factor. In particular, in the lead power factor, the terminal voltage becomes larger than the lag power factor. However, the output voltage depends on the input power factor. Therefore, optimal power factor control is necessary to obtain the output voltage using the output voltage of a reference. In order to obtain the maximum voltage transfer index of the matrix converter, the input current phase is made equal to the e.m.f. phase of the generator.

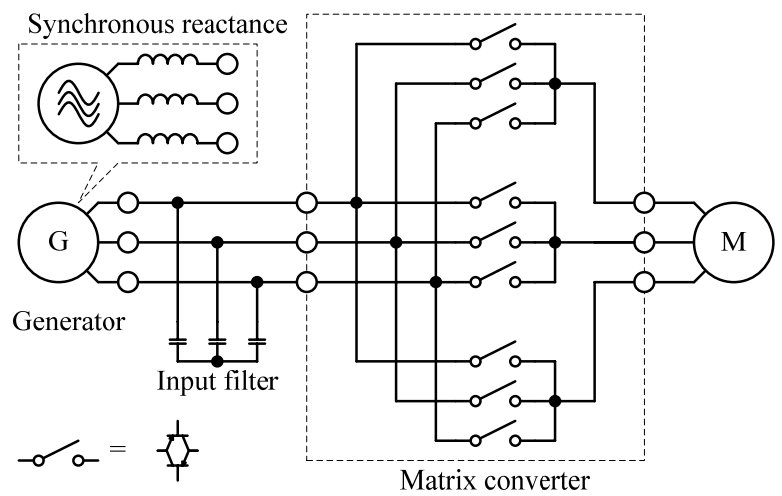

Fig. 1. System configuration diagram
Fig. 4 shows the experimental results obtained with a generator motor system. The output frequency command is $50 \mathrm{~Hz}$ (rated). The proposed control method can also be used to control the motor load. Clean sinusoidal input current waveforms are obtained, and the total harmonic distortion (THD) of the input current is $3.7 \%$. Moreover, the THD of output current is $1.7 \%$.

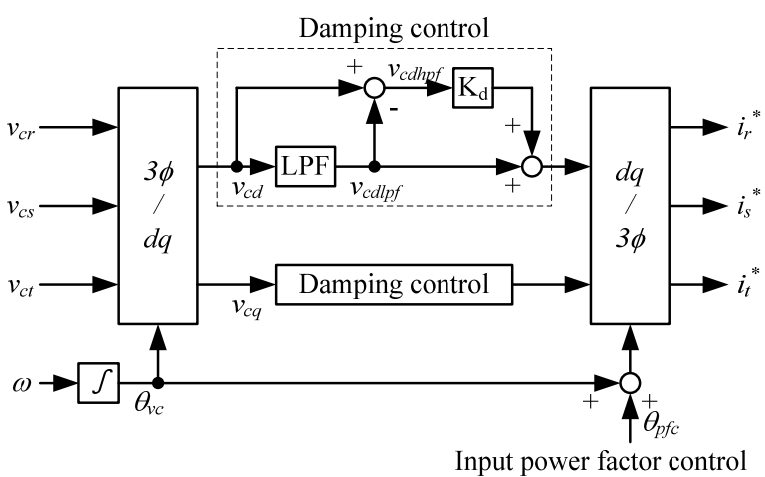

Fig. 2. Block diagram of the proposed stability control

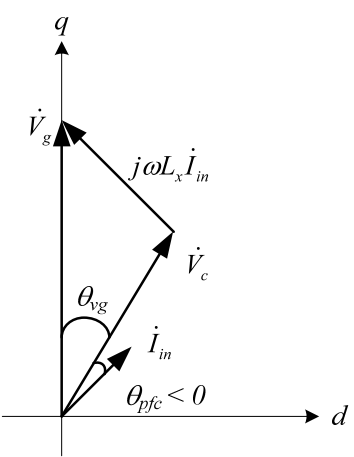

(a) Lag power factor $\left(\theta_{p f c}<0\right)$

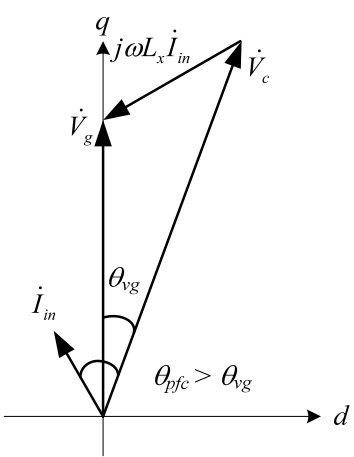

(b) Lead power factor $\left(\theta_{p f c}>\theta_{v g}\right)$
Fig. 3. Relationship among the input current, terminal voltage of the generator and e.m.f. of the generator

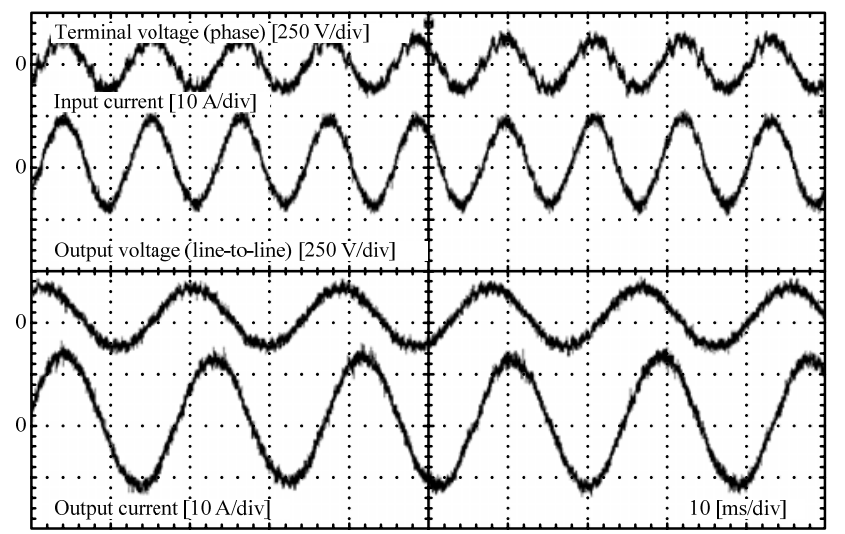

Fig. 4. Experimental waveforms obtained with induction motor load 


\section{発電機を電源とする \\ マトリックスコンバータの制御法}

学生員 春名順之介* 正 員 伊東 淳一*

\section{Control Strategy of a Matrix Converter with a Generator as Input}

Junnosuke Haruna*, Student Member, Jun-ichi Itoh*, Member

This paper describes a strategy for control of the input current of a matrix converter with a generator as the input. The line impedance is larger than the power grid when the generator is used as the input of the matrix converter. The resonance between the synchronous reactance of the generator and the input capacitance results in unstable behavior of the matrix converter. For a stable operation, stability control is provided to the rotating frame on the generator side. With the proposed method, both generator current and output voltage can be controlled, regardless of the generator speed. In addition, optimal input power factor control is proposed for achieving the maximum modulation index of the matrix converter.

This study confirms the validity of the proposed control strategy on the basis of the results of simulations and experiments. Oscillations in the generator terminal voltage and current can be suppressed by using the proposed stability control. Moreover, the proposed control helps achieve stable operations at a motor load of $1.5 \mathrm{~kW}$, and the THD of the input current is reduced to $3.7 \%$.

キーワード：マトリックスコンバータ, 同期発電機, 同期リアクタンス, 入力電流安定化制御, 最適入力力率制御

Keywords: matrix converter, synchronous generator, synchronous reactance, input current stability control, optimal input power factor control

\section{1. はじめに}

近年，直流リンクを介さずに，商用電源から任意の電圧， 周波数の交流に直接変換可能なマトリックスコンバータが 注目を浴び, 盛んに研究されている(1) (13)。その背景として, マトリックスコンバータは従来の PWM 整流器とインバー 夕からなる Back-to-Back システムと比較すると, 小形, 軽 量, 長寿命, 高効率の利点を有する。また, マトリックス コンバータの高効率化に貢献する逆耐圧を持つ IGBT が開 発され，実用化されているため，様々な用途へのマトリッ クスコンバータの適用が期待されている。

主な適用例として，エレベータやポンプ，空調設備等の 電動機駆動用途が挙げられる。応用先としてその他にも多 数検討されており, 一例として風力発電やハイブリッド $\mathrm{EV}$ への適用が考えられている。こうした用途では，マトリッ クスコンバータの入力部には発電機の接続が予想される。

一方，マトリックスコンバータの制御方法の課題として，

\footnotetext{
*長岡技術科学大学

干 940-2188 長岡市上富岡町 1603-1

Nagaoka University of Technology

1603-1, Kamitomioka, Nagaoka 940-2188
}

出力電圧と入力電流の同時制御が挙げられる。マトリック スコンバータは入力電圧を直接変換して出力電圧を制御す るため, 入力電圧が変動した場合, 出力電圧は低下する。特 にマトリックスコンバータと発電機の組み合わせを考慮す ると, 以下の 3 つの課題が考えられる。

（1）発電機は出力インピーダンスが大きく, 例えば, マ トリックスコンバータと同期発電機が接続された場合では, 発電機の同期リアクタンスは数十\%となり, 入力フィルタ コンデンサとの間で共振が発生する。特に出力電力を一定 に制御する場合, 等価的に負性抵抗が現れ不安定を助長し, 安定性を悪化させる。

（2）発電機は運転状況により逆起電力の振幅と周波数 が変動するため, マトリックスコンバータの入出力波形制 御を変動に追従して制御しなくてはならない。特に発電機 側の力率は発電機の効率, およびマトリックスコンバータ の電圧利用率に大きく影響するため, 両方が最大となる力 率に調節する必要がある。

（3）電源に発電機，負荷に電動機を適用した場合のマ トリックスコンバータの運転例はこれまで報告されておら ず，入出力の制御で干渉を起こす可能性がある。 これまでに, 課題 (1)に関しては入力フィルタの共振を 
抑制する制御や系統インピーダンスが高い場合についての 検討はいくつか報告されている(6)(7)(11)。しかし, 発電機の ように極端にインピーダンスが高い場合や電源周波数が大 きく変動する場合については報告例がなく，またモデリン グや適用限界に関して明らかでないと思われる。課題 $(2)$, (3)については，これまでにマトリックスコンバータのス イッチング方式(1) (5) については多数の研究が発表されてい るが，マトリックスコンバータの用途について着目した例 はそれほどなく，特に発電機と電動機をマトリックスコン バータに接続し，実際に実験により検証した例については 筆者らの知る限り報告されていない。

そこで, 本論文では発電機を入力に接続したマトリック

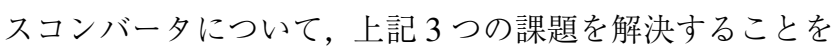
目的とする。

まず課題 $(1)$ を解決するために, 発電機の同期リアク夕 ンスがシステムへ及ぼす影響について考察し, 不安定化す る原因を解明する。また, システムを安定化するために, 発 電機の端子電圧の振動成分に基づきマトリックスコンバー 夕の入力電流指令を調整するダンピング制御を適用する。 提案方式は回転座標上で制御することで, 発電機の回転数 に関係なく制御可能である。

次に課題 $(2)$ を解決するために, 入力電流位相に着目し て発電機の逆起電力と端子電圧, 出力電圧の関係を明らか にした上で，発電機の効率およびマトリックスコンバー夕 の電圧利用率を最大にするための最適入力力率制御を提案 する。

さらに課題 $(3)$ に対応して, 本稿では入力に同期発電機, および出力に誘導電動機を接続した実験機にて安定した制 御を実現し，その有用性を検討している。提案制御法を用 いることにより，発電機側の電圧，電流が安定に制御でき ることを確認するとともに, 発電機と電動機の干渉を起こ すことなく入出力波形を良好に制御できることを確認する。

\section{2. 発電機を接続したマトリックスコンバータの 問題点}

Fig. 1 にマトリックスコンバー夕に発電機と電動機を接 続したシステム図を示す。発電機を同期発電機とし，巻線 抵抗を無視するとすれば，発電機の等価回路は電源と同期 リアクタンスを直列に接続した回路で表せる。従って，入 カフィルタはコンデンサのみを接続することで構成できる。 本章では発電機の影響と安定性を検討するために, 入力フィ ル夕について考察を行う。

Fig. 2 に入力フィルタの一相分等価回路を示す。Fig. 2 で は負荷は抵抗としているが, マトリックスコンバータの出 力電圧を一定に制御することを考えると，実際には発電機 の端子電圧により抵抗が変化する定電力負荷である。マト リックスコンバータの負荷電流 $i_{o}$ は, 発電機の端子電圧 $v_{c}$, 負荷電力を $P_{o}$ とすると, (1) 式で表される。

$$
i_{o}=P_{o} / v_{c}
$$

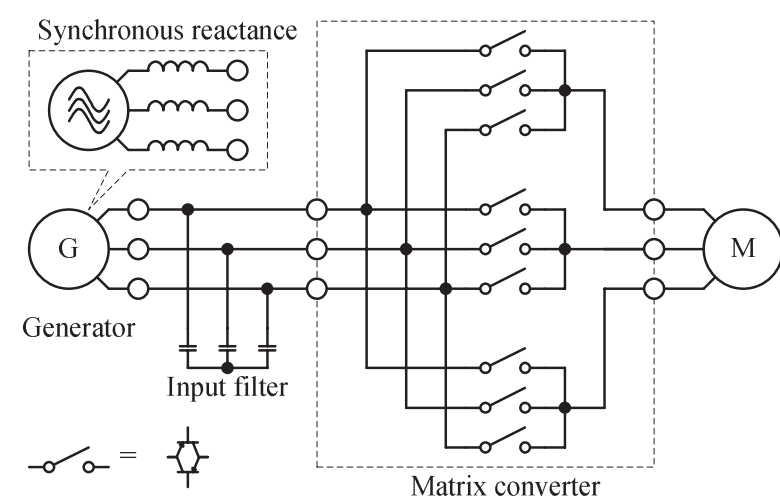

Fig. 1. Configuration diagram of Generator-matrix converter-motor system.

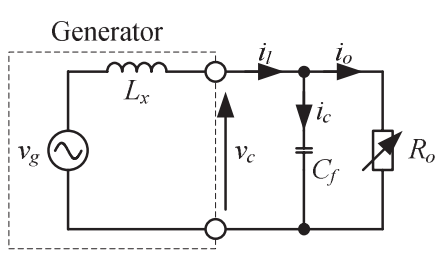

Fig. 2. Single phase equivalent circuit of the input filter including synchronous reactance.

負荷電力 $P_{o}$ を一定とすれば，(1) 式は非線形方程式とな るので線形近似を行う。 $i_{o}, v_{c}, P_{o}$ を定常成分とリプル成 分で表し，(1) 式を展開することで (2) 式を得る。ただし, $P_{o s}, v_{c s}, i_{o s}$ は定常成分, $\Delta P_{o}, \Delta v_{c}, \Delta i_{o}$ はリプル成分で ある。

$$
P_{o s}+\Delta P_{o}=v_{c s} i_{o s}+\Delta v_{c} i_{o s}+v_{c s} \Delta i_{o}+\Delta v_{c} \Delta i_{o}
$$

(2) 式のリプル成分同士の積を無視し, 負荷電流の定常 成分とリプル成分に分離して整理すると，(3)，(4) 式が得 られる。ただし， $R_{o}$ は定常的な電力に相当する負荷抵抗で ある。

$$
\begin{gathered}
i_{o s}=\frac{P_{o s}}{v_{c s}}=\frac{1}{R_{o}} v_{c s} . \\
\Delta i_{o}=\frac{\Delta P_{o}-\Delta v_{c} i_{c s}}{v_{c s}}
\end{gathered}
$$

（4）式に扔いて, 負荷電力を一定に制御すると $\Delta P_{o}=0$ と なる。従って, 入力電流リプル $\Delta i_{o}$ はフィードバックゲイ ン $K_{0}$ を用いて (5) 式で表される。

$$
\Delta i_{o}=-\frac{i_{o s}}{v_{c s}} \Delta v_{c}=-K_{0} \Delta v_{c}
$$

Fig. 3 に(5) 式を用いた入力フィルタのブロック図を示 す。 $H_{1}(s)$ と $H_{2}(s)$ はそれぞれ, 定常分とリプル成分を分離 するフィルタであり, それぞれローパスフィルタとハイパス フィルタのような特性を有しており， $H_{1}(s)+H_{2}(s)=1$ で ある。このとき, 入力フィルタの伝達関数は (6) 式となる。 


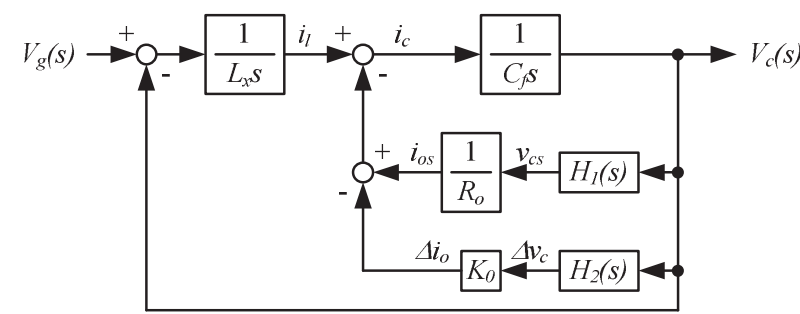

Fig. 3. Block diagram of the input filter.

$$
\frac{V_{c}(s)}{V_{g}(s)}=\frac{\frac{1}{L_{x} C_{f}}}{s^{2}+\frac{1}{C_{f}}\left(\frac{1}{R_{o}} H_{1}(s)-H_{2}(s) K_{0}\right) s+\frac{1}{L_{x} C_{f}}}
$$

入力が発電機の場合は同期リアクタンスが大きいため, フィルタの共振周波数を設定する場合，コンデンサ容量を 小さくする必要がある。しかし，フィルタコンデンサを小 さくした場合，電圧のリプルが大きくなり $K_{0}$ のフィード バックが増加する。 $K_{0}$ の係数は負であるため, 制動係数が 低下し，フィル夕共振によって入力側が不安定になる。ま た，系統電源を接続する場合，共振を抑制するためにフィ ルタリアクトルに並列にダンピング抵抗を挿入すると効果 的であるが，発電機の場合，電源と同期リアクタンスを分 離できないため，ダンピング抵抗を並列に挿入できない。 従って, 発電機電源時には, フィル夕の共振を抑制し, シ ステムを安定にする制御が必要となる。

\section{3. 入力電流安定化制御}

前章にて，発電機を接続した場合の入力フィルタについ て検討し，問題点を述べた。マトリックスコンバータは出 力電圧と同時に入力電流が制御可能なので，入力電流の制 御に着目した安定化手法を提案する。

系統に接続されているマトリックスコンバータにおいて は，バンドストップフィルタを用いて，系統電圧のリプル 成分だけを抜き出して安定化をはかる制御方式が提案され ている。しかし，発電機の場合，運転速度に応じて，電源 の周波数が変化するので，ストップ周波数を速度に応じて 変化させなくてはならず，リプル分だけを抽出することは 困難である。そこで，本論文では回転座標上で安定化制御 を行う手法を提案する。

Fig. 4 に提案する入力電流安定化制御のブロック図を示 す。提案法では, 発電機の端子電圧 $v_{c r}, v_{c s}, v_{c t}$ を検出し, 回転座標変換を行う。回転座標上では基本波成分は直流に, 高調波成分は直流リプルに変換される。基本波成分と高調 波成分を分離するために，時定数の大きいローパスフィル 夕を用いて直流成分のみを抽出する。ここで，入力側の安 定化のために，ダンピング制御 (7)(14) を導入する。元の直流 からローパスフィルタの出力を減算し, 直流リプルのみを 抽出する。その後，分離した高調波成分をゼロとするよう にゲイン $K_{d}$ を乗算し，基本波成分に重畳する。最後に三

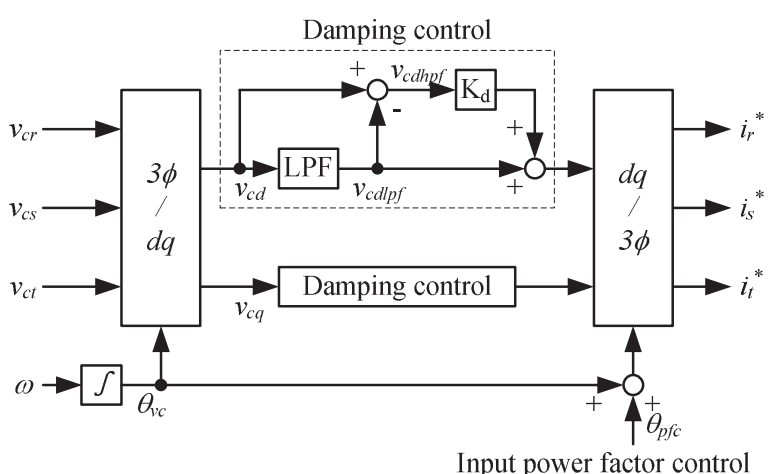

Fig. 4. Block diagram of the proposed input current stability control.

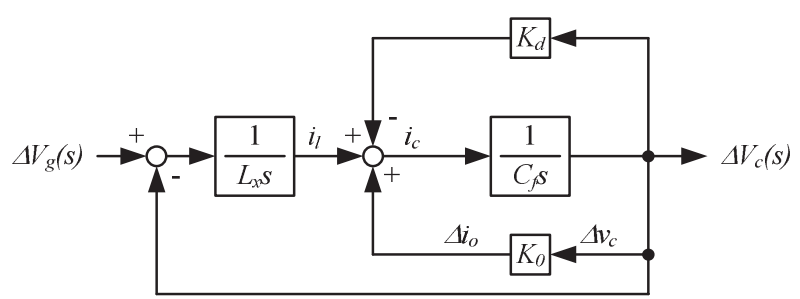

Fig. 5. Block diagram of the transfer function of the input current stability control.

相座標変換を行い, 入力電流指令 $i_{r}^{*}, i_{s}^{*}, i_{t}^{*}$ とする。

提案方式の特徵は, 発電機の回転数に応じたダンピング 制御が可能な点にある。回転座標上では, 逆起電力の基本 波周波数は発電機の回転数に依存せずすべて直流となるた め，带域を選別する周波数を容易に可変できる。また，基 本波成分以外を取り出すバンドストップフィルタをローパ スフィルタに置き換えられるため, 演算が簡単となる。さ らに, 入力電流指令には, 発電機の端子電圧の振動を抑制 する指令が重畳されているため, 端子電圧の変動を減衰し, かつ，入力電流はひずみのない正弦波に制御できる。

Fig. 5 にリプル分のみを考慮した入力電流安定化制御の 伝達関数のブロック図を示す。バンドストップフィルタを 理想とし，リプル分のみを考えているので，ダンピング制 御は $V_{c}$ からゲイン $K_{d}$ による負帰還にみえる。このとき， 伝達関数は (7) 式で表される。

$$
\frac{\Delta V_{c}(s)}{\Delta V_{g}(s)}=\frac{\frac{1}{L_{x} C_{f}}}{s^{2}+\frac{1}{C_{f}}\left(K_{d}-K_{0}\right) s+\frac{1}{L_{x} C_{f}}}
$$

(6) 式と比較すると，ダンピングゲイン $K_{d}$ によって減衰 係数が調整可能であることがわかる。(7)式の減衰係数らを (8) 式に示す。

$$
\zeta=\frac{1}{2} \sqrt{\frac{L_{x}}{C_{f}}}\left(K_{d}-K_{0}\right)
$$

よって, ダンピングゲイン $K_{d}$ は (9) 式で求められる。(9) 式より所望の制動係数となるように $K_{d}$ を求める。 


$$
K_{d}=K_{0}+2 \sqrt{\frac{C_{f}}{L_{x}}} \zeta
$$

\section{4. 最適入力力率制御}

Fig. 4 において, 三相座標変換する際に, 発電機の端子電 圧の回転角 $\theta_{v c}$ に入力力率調整角 $\theta_{p f c}$ を加えることによっ てマトリックスコンバータの入力力率の調整が可能となる。 発電機を電源とする場合，入力力率の調整によって端子電 圧が変動する。また，入力電流は同期リアクタンスによっ て逆起電力との間に位相遅れが発生する。本章では入力力 率，端子電圧拉よび電圧利用率の関係を明らかにし，入力 力率制御の最適化を提案する。

$\langle\mathbf{4} \cdot 1\rangle$ 入力力率と発電機の端子電圧の関係 Fig. 6 に 入力力率角 $\theta_{p f c}$ を変動させた場合の入力電流ベクトル $\dot{I}_{i n}$, 発電機の端子電圧べクトル $\dot{V}_{c}$, 発電機の逆起電力ベクトル $\dot{V}_{g}$ の関係を示す。なお，これらのベクトルはフェーザベク トルである。Fig. 6 では, d 軸を磁束方向, q 軸を逆起電力 方向と定義する。従って, 発電機の逆起電力 $\dot{V}_{g}$ は q 軸上 に位置する。次に, 発電機の出力力率とマトリックスコン バータの入力力率の関係について述べ，マトリックスコン バータの入力力率を定義する。

発電機の端子電圧ベクトル $\dot{V}_{c}$ は, 入力電流ベクトル $\dot{I}_{i n}$ と発電機の同期リアクタンスによって電圧降下が発生する。 (10) 式に, 発電機の逆起電力と端子電圧, 入力電流の関係 式を示す。ただし， $\dot{V}_{g}=j v_{g}$ で， $v_{g}$ は発電機の逆起電力心゙ クトルの q 軸成分ある。

$$
\dot{V}_{c}=\dot{V}_{g}-j \omega L_{x} \dot{I}_{i n}
$$

(10) 式より，フィルタコンデンサのアドミタンスを $Y_{c}$ と すると,フィル夕電流は (11) 式となる。

$$
\dot{I}_{f}=j Y_{c}\left(\dot{V}_{g}-j \omega L_{x} \dot{I}_{i n}\right)
$$

次に, 入力電流ベクトル $\dot{I}_{\text {in }}$ はマトリックスコンバータの 電流 $\dot{I}_{m c}$ とフィル夕電流 $\dot{I}_{f}$ を用いて (12) 式で表される。

$$
\dot{I}_{i n}=\dot{I}_{m c}+\dot{I}_{f}
$$

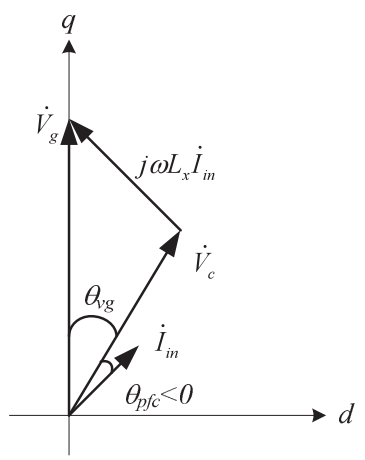

(a) Lag power factor $\left(\theta_{p f c}<0\right)$

Fig. 6. Relationship among the input current, generator terminal voltage and electromotive force of the generator.
発電機の出力力率は発電機の端子電圧ベクトル $\dot{V}_{c}$, 入力 電流ベクトル $\dot{I}_{i n}$ から定義され，マトリックスコンバータの 入力力率は, 端子電圧ベクトル $\dot{V}_{c}$ とマトリックスコンバー 夕の電流 $\dot{I}_{m c}$ から定義される。ここで, 発電機の同期リア クタンスは数十\%あるのに対し, フィルタコンデンサのア ドミタンスは数\%程度である。たとえば，発電機の同期リ アクタンスを 50\%，フィルタコンデンサのアドミタンスを $10 \%$ とすると，(10) (12) 式よりフィル夕電流 $\dot{I}_{f}$ は入力電 流の $5 \%$ となるためフィル夕電流を無視できる。フィルタ 電流を無視する場合, 発電機の出力力率とマトリックスコ ンバータの入力力率は同義となる。

以上をふまえ, 入力力率角 $\theta_{p f c}$ を発電機の端子電圧べク トル $\dot{V}_{c}$ と入力電流べクトル $\dot{I}_{i n}$ との位相差と定義する。ま た, (10) 式より生じる発電機の逆起電力ベクトル $\dot{V}_{g}$ と端 子電圧ベクトル $\dot{V}_{c}$ の位相差を負荷角とする。なお, 入力力 率は, 端子電圧べクトル $\dot{V}_{c}$ を基準として $\mathrm{d}$ 軸方向に入力 電流べクト $\dot{I}_{\text {in }}$ が位置する場合を遅れ方向とし, q 軸方向に 位置する場合を進み方向とする。

Fig. 6(a) は入力力率を遅れ制御 $\left(\theta_{p f c}<0\right)$ した場合のべ クトル図, (b) は進み力率制御 $\left(\theta_{p f c}>\theta_{v g}\right)$ 時のベクトル図 である。発電機の端子電圧は逆起電力に対して, 入力電流 と同期リアクタンスによって電圧降下が発生する。遅れ力 率制御の場合, (a) より, 発電機の逆起電力に対して振幅が 減少する方向に変動する。一方, 進み力率制御の場合, (b) より, 発電機の逆起電力に対して振幅は増加する方向に変 動する。つまり, 発電機電源時は入力力率を進み制御する ことによって端子電圧を増加できる。

$\langle\mathbf{4} \cdot \mathbf{2}\rangle$ 出力電圧と入カカ率の関係 マトリックスコ ンバータは自由に入力力率を制御できるが，マトリックス コンバータを含む直接形電力変換器では入力電圧を直接入 イッチングによって変調するので, 出力電圧は入力力率に よって変動する。(13) 式にマトリックスコンバータの出力 電圧最大值 $V_{\text {out }}$ と発電機の端子電圧の最大值 $\left|\dot{V}_{c}\right|$, 入力力率 $\cos \theta_{p f c}$ の関係を示す。ただし, $\lambda$ は変調率 $(0 \leqq \lambda \leqq 0.866)$ である。

$$
V_{\text {out }}=\lambda\left|\dot{V}_{c}\right| \cos \theta_{p f c}
$$

従って, 変調率 $\lambda$ を一定とすると, Fig. 6(a) では発電機の 端子電圧 $\dot{V}_{c}$ が小さくなるので出力電圧は小さくなり, (b) では $\dot{V}_{c}$ は増加するが, 位相差 $\theta_{p f c}$ が大きいため力率が悪 化し, 所望の出力電圧が得られない。つまり, 発電機電源 の場合, 進み力率制御によって発電機の端子電圧が増加す るが, 力率が悪化するため, 端子電圧上昇分だけ出力電圧 が増加するとは限らない。そこで, 本論文では, 発電機の 逆起電力を基準とし, 入力力率と出力電圧の関係を議論し た上で, 電圧利用率 (入力電圧と出力電圧の比) が最大と なる最適入力力率制御を検討する。ただし, ここでは簡単 のため円筒形同期発電機を想定している。

Fig. 6 に扔いて, 発電機の端子電圧と入力電流を用いて 発電機の複素電力 $\dot{P}_{c}$ を求めると, (10) 式の関係から (14) 


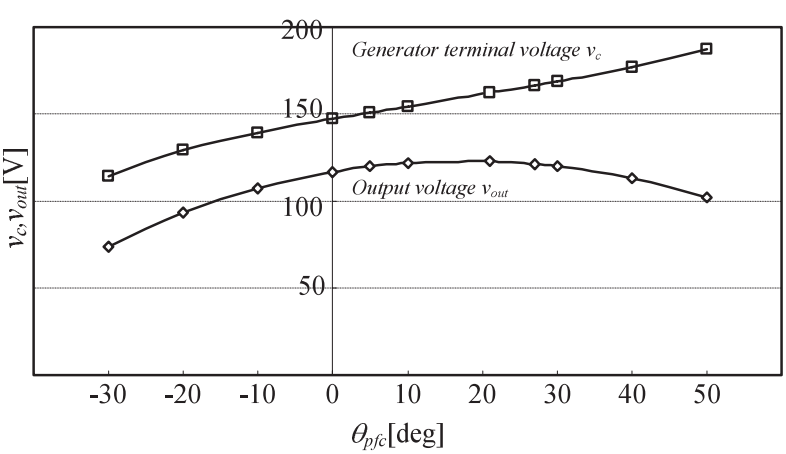

Fig. 7. The input power factor between generator terminal voltage and output voltage.

Table 1. Generator parameters.

\begin{tabular}{|c|c|c|c|}
\hline Rated power & $3.7 \mathrm{~kW}$ & Stator resistance & $0.695 \Omega$ \\
\hline Rated rotational frequency & $1800 \mathrm{rpm}$ & d-axis inductance & $6.2 \mathrm{mH}$ \\
\hline Rated Voltage (line-to-line) & $180 \mathrm{Vrms}$ & q-axis inductance & $15.3 \mathrm{mH}$ \\
\hline Back e.m.f. (line-to-line) & $150 \mathrm{Vrms}$ & Number of pole & 6 \\
\hline
\end{tabular}

式が得られる。ただし， $i_{d}$ は入力電流 $\dot{I}_{i n}$ の $\mathrm{d}$ 軸成分， $i_{q}$ は q 軸成分である。

$$
\dot{P}_{c}=\overline{\dot{V}}_{c} \dot{I}_{c}=v_{g} i_{q}+j\left\{\omega L_{x}\left(i_{d}^{2}+i_{q}^{2}\right)-v_{g} i_{d}\right\}
$$

(14) 式では，実部は有効電力であるため，瞬時有効電力 $P$ は (15) 式となる。

$$
P=v_{g} i_{q}
$$

(14)，(15) 式より，入力力率 $\cos \theta_{p f c}$ は (16) 式で求めら れる。

$$
\cos \theta_{p f c}=\frac{P}{\left|\dot{P}_{c}\right|}=\frac{v_{g} i_{q}}{\sqrt{v_{g}^{2} i_{q}^{2}+\left\{\omega L_{x}\left(i_{d}^{2}+i_{q}^{2}\right)-v_{g} i_{d}\right\}}}
$$

(16) 式を (13) 式に代入し, 整理すると, 出力電圧 $V_{\text {out }}$ は (17) 式となる。

$$
V_{\text {out }}=\lambda v_{g} \frac{i_{q}}{\sqrt{\left(i_{d}^{2}+i_{q}^{2}\right)}}
$$

(17) 式から明らかなように, 出力電圧を最大とするには $i_{d}=0$ となるように入力電流位相を調整すればよい。この とき, 逆起電力に対し電圧利用率が最大となり, 出力電圧 $V_{\text {outmax }}$ は (18) 式で表される。また, 同時に $\mathrm{d}$ 軸電流がゼ ロであることから，発電機の効率は最大となる。

$$
V_{\text {out } \max }=\lambda v_{g} \frac{i_{q}}{\sqrt{i_{q}^{2}}}=\lambda v_{g}
$$

このとき, 発電機の端子電圧は逆起電力の $1 / \cos \theta_{v g}$ となる。

Fig. 7 に Table 1 の発電機モデル，拉よび, Table 2 のシ

\begin{tabular}{|c|c|c|c|}
\hline Output power (constant) & $1.5 \mathrm{~kW}$ & Modulation index & 0.8 \\
\hline Output power factor & 0.8 & Output frequency & $90 \mathrm{~Hz}$ \\
\hline Filter ca & $6.6 \mu \mathrm{F}(5.6 \%)$ & Carrier frequency & $10 \mathrm{kHz}$ \\
\hline \multicolumn{2}{|c|}{ Modulation method } & \multicolumn{2}{|c|}{ Virtual AC/DC/AC conversion ${ }^{(2)}$} \\
\hline \multicolumn{2}{|c|}{ Commutation } & \multicolumn{2}{|c|}{ Voltage commutation } \\
\hline \multicolumn{2}{|c|}{ Commutation time } & \multicolumn{2}{|l|}{$2.5 \mu \mathrm{s}$} \\
\hline \multirow{3}{*}{ Load } & Simulation & \multicolumn{2}{|c|}{ Current source load } \\
\hline & RL load & \multicolumn{2}{|c|}{$6.25 \Omega, 5 \mathrm{mH}$} \\
\hline & Motor load & \multicolumn{2}{|c|}{$1.5 \mathrm{~kW} 4$ pole Induction motor } \\
\hline
\end{tabular}
ミュレーション条件を用いた場合の, 入力力率の変動に対す る発電機の端子電圧と出力電圧の変動のシミュレーション 結果を示す。Fig. 7 は純粋に入力力率の変化による出力電圧
Table 2. Simulation and experimental conditions.

の影響を確認するため, 負荷電力は一定している。マトリッ クスコンバータの入力力率を 1 に制御すると $\left(\theta_{p f c}=0\right)$, 出力電圧は電圧指令が $120 \mathrm{~V}$ なのに対し, $115 \mathrm{~V}$ となり, 電 圧指令に応じた出力電圧が得られない。また, 遅れ力率制 御を行う場合 $\left(\theta_{p f c}<0\right)$ は, 発電機の端子電圧と出力電圧 の両方が低下しており, Fig. 6(a)のベクトル図の動作が確 認できる。一方, 進み力率制御の場合 $\left(\theta_{p f c}>0\right)$ は, 発電 機の端子電圧は上昇を続けるが, 出力電圧はある角度まで 上昇し，それ以降は減少している。これは Fig. 6(b) のベク トル図により考察した結果と一致している。さらに, この 条件では $i_{d}=0$ となる位相角を机上計算より求めると $\theta_{p f c}$ $=26 \mathrm{deg}$ となる。シミュレーション結果では, このとき出 力電圧は $121 \mathrm{~V}$ で最大となって扔り, 出力電圧指令に一致 する。なお，このとき, 発電機の端子電圧の理論值は $168 \mathrm{~V}$ であり, シミュレーション結果とほほ一致している。以上 から，検討結果の妥当性が確認できた。

\section{5. 発電機の電圧変動補償}

発電機の逆起電力は発電機の回転数に応じて变動するた め, マトリックスコンバータの入力端子電圧は発電機の運 転状況によって変動する。従って, 所望の出力電圧を得る ためには, 発電機電圧の変動に応じて出力電圧振幅を補償す る必要がある。マトリックスコンバータの出力電圧は (13) 式から明らかなように電源電圧の変動だけでなく, 入力力 率によっても変動するが, 従来は常に力率 1 で制御するの で, 従来ではマトリックスコンバータの入力端子電圧を検 出し, 電圧変動に応じて出力電圧を補償すればよい。しか し, 発電機入力の場合, 入力力率は運転条件により变化す るため, 端子電圧を検出しただけは入力力率の変動分を補 償できず，出力電圧の変動を完全に補償できない。

そこで, 本稿では, 逆起電力に着目した出力電圧の補償 方法を提案する。(18) 式から明らかなように， $i_{d}=0$ で制 御しているときは, マトリックスコンバータの出力電圧は 逆起電力のみに比例する。そこで, 逆起電力の変動の大き さに反比例して出力電圧を補償する。なお, 逆起電力は発 電機の速度から求められ, 速度は発電機の磁極位置センサ を用いて検出する。

Fig. 8 に提案する出力電圧補償制御を用いたシステム制 御ブロック図を示す。発電機の磁極位置センサより, 磁極 位置を検出し, PLLによって逆起電力位相, および周波数 


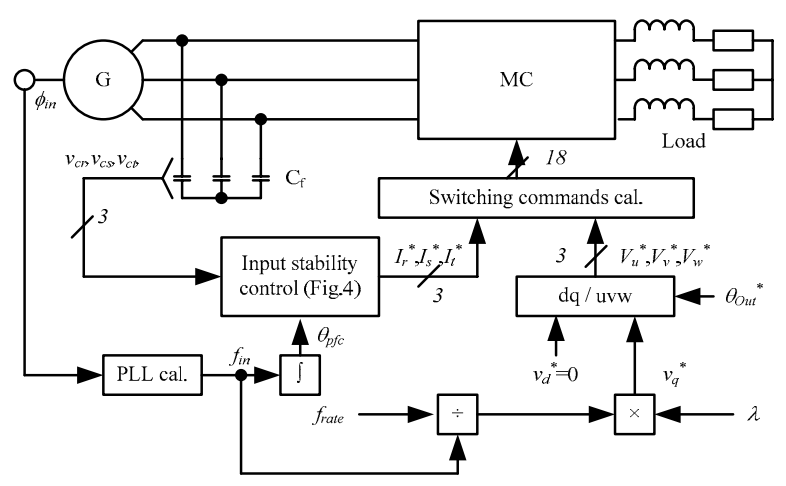

Fig. 8. The system control block diagram using the proposed output voltage compensation.

$f_{\text {in }}$ を演算する。発電機の逆起電力位相は入力電流安定化制 御に使用する。逆起電力は周波数に比例するため, 検出し た周波数で変調率 $\lambda$ を除算することで, 発電機の逆起電力 の減少分だけ変調率 $\lambda$ が増加し, 出力電圧を補償できる。

なお, 出力電圧の最大值は逆起電力の 0.866 倍以下であ り, 出力電圧指令がこの值を超えるときは過変調となり, 入 出力の波形は悪化する。

\section{6. 実験結果}

本章ではこれまでに提案した制御法を用いてRL負荷，お よび誘導電動機負荷で実験を行い，その有用性を検討する。

$\langle\mathbf{6} \cdot \mathbf{1}\rangle$ RL 負荷実験結果 Fig. 9 に Table 1 の同期発 電機と Table 2 の実験条件を用いた場合の RL 負荷による 実験結果を示す。Fig. 9(a) は入力電流安定化制御を行わな い場合，(b) は提案制御手法を導入した場合の実験結果であ り，(a)，(b) ともに，同条件で実験を行っている。(a)では フィルタの共振が発生し, 発電機の端子電圧, 入力電流に 大きなひずみが生じている。また，入力ひずみが出力側に も影響し出力側もひずんで㧍り, システムが不安定となっ ているのが確認できる。従って，2 章で示した発電機を接 続したマトリックスコンバータの不安定動作と実験結果が 一致している。一方, (b) 上り, 入力電流安定化制御を導入 することでフィル夕共振を抑えることができ，発電機の端 子電圧，入力電流ともに，ひずみを抑制できているのが確 認できる。また，入力側が安定に制御できるため, 出力側 にもひずみが発生せず, 出力電圧, 電流ともに良好な結果 が得られている。

Fig. 10 にRL負荷における，入力力率を変動させた場合 の発電機の端子電圧, 出力電圧の関係を示す。Table 2 より,

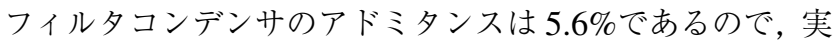
験においてもフィル夕電流の影響を無視することができ， 発電機の出力力率とマトリックスコンバータの入力力率は 等しい。シミュレーション結果と同様に，マトリックスコ ンバータの入力力率を 1 に制御した場合 $\left(\theta_{p f c}=0 \mathrm{deg}\right)$, 出 力電圧は $108 \mathrm{~V}$ となり, 所望の出力電圧が得られていない のが確認できる。 $\theta_{p f c}=26 \mathrm{deg}$ としたときの発電機の端子 電圧は理論值 $172 \mathrm{~V}$ に対し, 実測值 $173 \mathrm{~V}$, 出力電圧は理論

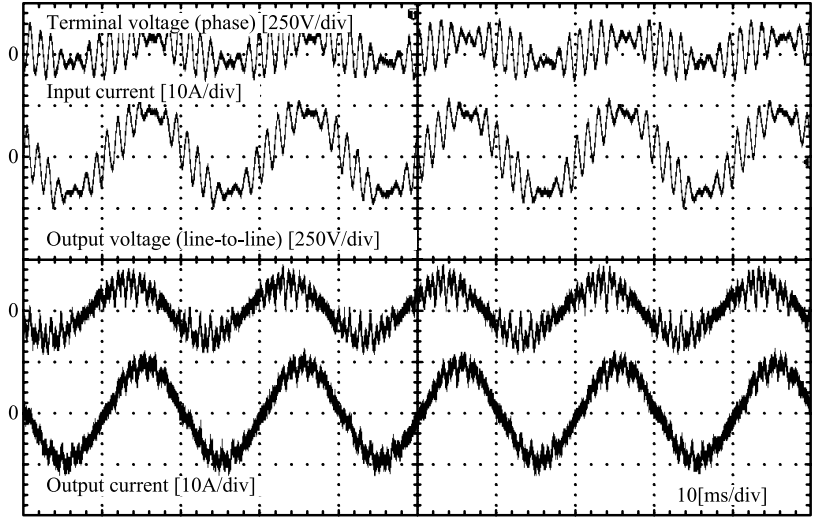

(a) Conventional control.

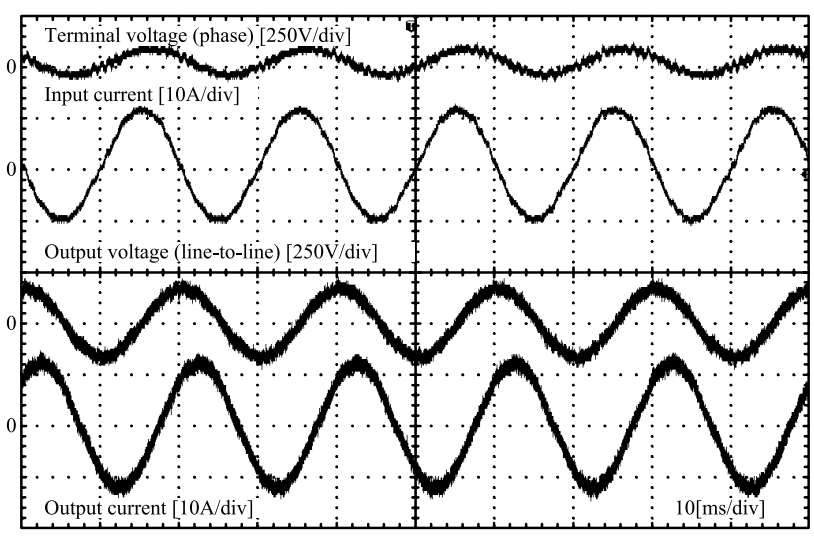

(b) Proposed input current stability control.

Fig. 9. Experimental waveforms with RL load.

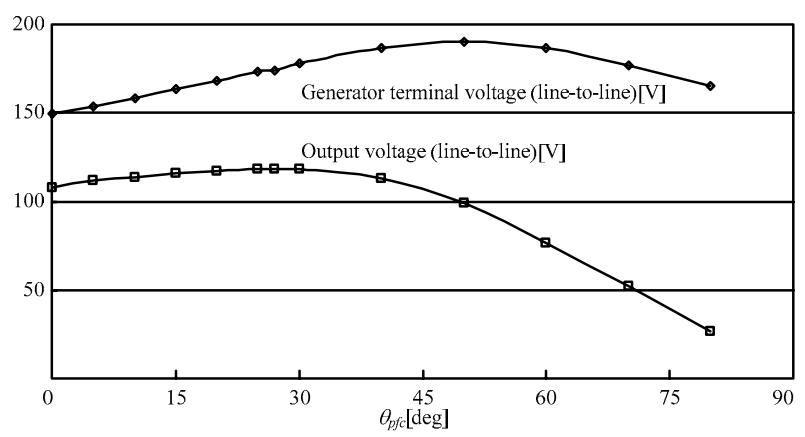

Fig. 10. Experimental waveforms with RL load.

值 $120 \mathrm{~V}$ に対し，実測值 $118 \mathrm{~V}$ となり，理論值と実測值が ほぼ一致することから, フィルタ電流の影響を無視ても影 響はない。以上より, 入力力率制御を行うことができ, 提 案する最適入力力率制御の妥当性が確認できる。な抧, 入 力力率を 1 に制御した場合, Fig. 7 のシミュレーション結 果と一致しない理由は, Fig. 7 では負荷電力一定であるの に対し, 実験結果では負荷抵抗一定であるためである。

$\langle\mathbf{6} \cdot 2\rangle$ 誘導電動機の負荷実験結果 Fig. 11 に Table 1 の同期発電機, Table 2 の誘導電動機負荷を用いて, 出力電 力を $1.5 \mathrm{~kW}$ としたときの実験結果を示す。誘導電動機の 制御には V/f 制御を用いている。誘導電動機負荷の場合も RL 負荷時と同様に，入力電流安定化制御によって発電機 の端子電圧, 入力電流にはフィル夕共振による大きなひず 


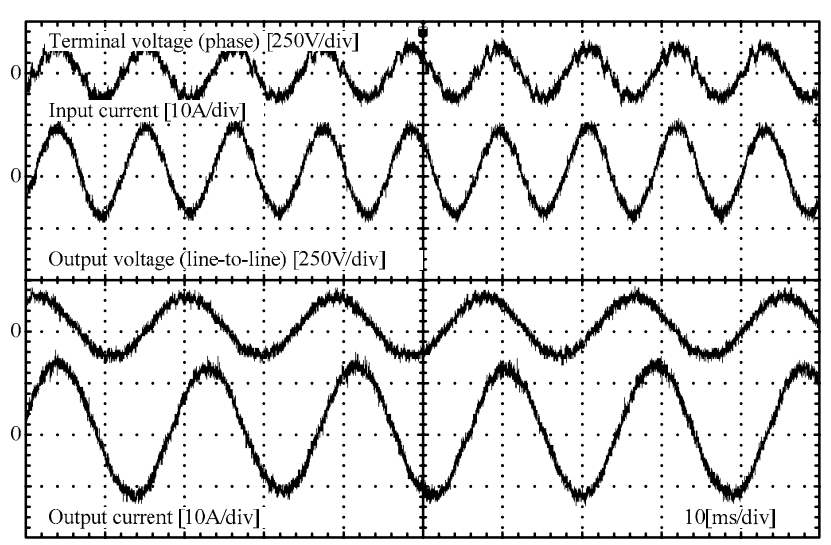

Fig. 11. Experimental waveforms with induction motor load.

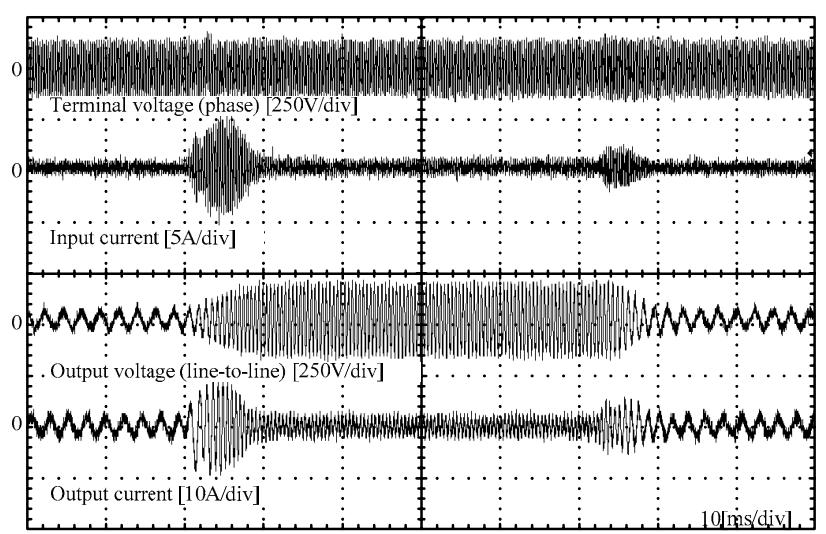

Fig. 12. Accelerating and decelerating result of the induction motor.

みや脈動が発生せず，正弦波状に制御できている。このと きの入力電流ひずみ率は $3.7 \%$, 出力電流ひずみ率は $1.7 \%$, 変換機効率は $95.7 \%$ となり，提案する安定化制御が誘導電 動機の駆動に影響を与えることなく，入出力を安定に制御 可能であることを示している。

$\langle 6 \cdot 3\rangle$ 誘導電動機の加減速実験結果 Fig. 12 に誘導 電動機の加減速実験結果を示す。誘導電動機は $150 \mathrm{r} / \mathrm{min}$ か ら $1500 \mathrm{r} / \mathrm{min}$ までを $0.3 \mathrm{sec} て ゙$ 加減速させている。本シス テムでは誘導機の急加速，減速によって入力電流が変動す る際に, 発電機の端子電圧が急激に上昇し, 不安定になる 可能性があるが, Fig. 12 より, 加減速時に入力電流が大き く上昇しても，発電機の端子電圧はほぼ一定值となってい るのが確認できる。同様に，減速時にも入力電流は上昇す るが, 端子電圧は一定に制御されている。従って，入力電 流安定化制御を用いることで，入力電流の急峻な变化に対 してもシステムを安定に制御可能であることが確認できる。 さらに，出力電圧，電流に着目すると，加減速の前後で大 きな脈動が発生せず，電動機の回転数を変化させてもシス テムに影響を及ぼさないのが確認できる。

$\langle 6 \cdot 4\rangle$ 同期発電機加減速実験結果 Fig. 13 に同期発 電機を定格回転数 $1800 \mathrm{r} / \mathrm{min}$ から $1350 \mathrm{r} / \mathrm{min}$ まで減速さ せ，その後定格回転数まで加速した加減速実験結果を示す。

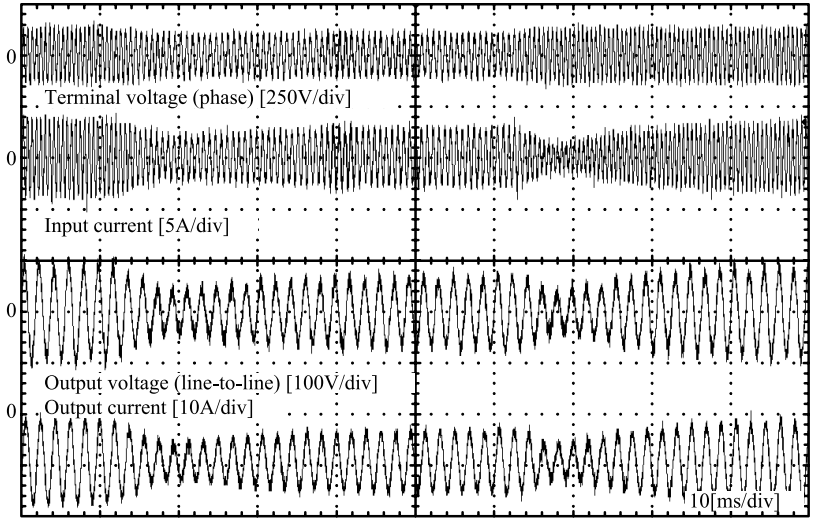

(a) without output voltage compensation.

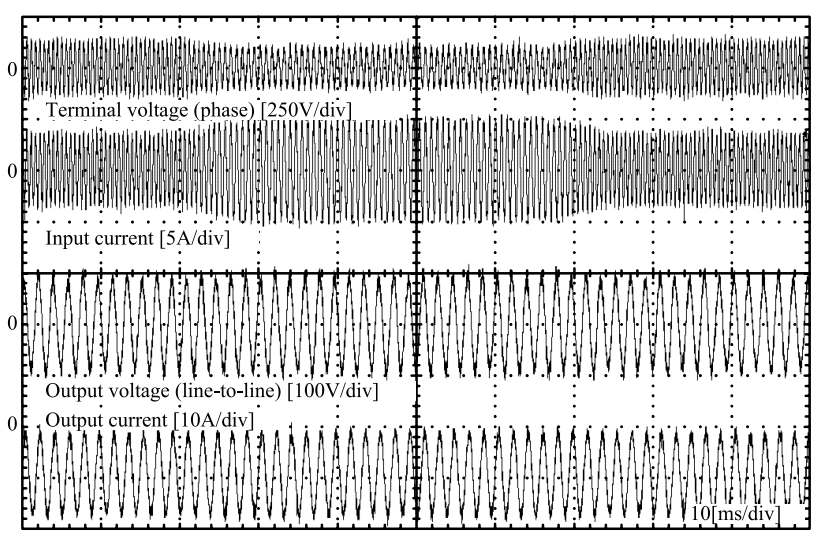

(b) Proposed output voltage compensation.

Fig. 13. Accelerating and decelerating result of the synchronous generator using proposed output voltage compensation.

マトリックスコンバータの出力電圧は同期発電機定格電圧 の $40 \%$ 一定とし, 同期発電機は $0.5 \mathrm{sec} て ゙$ 加減速させてい る。Fig. 13(a) は提案する出力電圧補償法を用いない場合, (b) は出力電圧補償を用いた場合の実験結果である。(a)よ り，提案電圧補償法を用いない場合，同期発電機が減速す ると発電機の端子電圧が減少し, 出力電圧も減少している のが確認できる。さらに，加減速の直後で大きく出力電圧 が下がっており, 発電機の運転状況が急に変化した場合, 出力側が不安定になることがわかる。一方, 出力電圧補償 法を用いた (b) では，発電機の端子電圧が減少した場合で も, 出力電圧は一定に制御できている。また, 出力電圧が 一定なので，発電機の端子電圧の減少によって入力電流が 増加するが, 入力電流は不安定になることなく制御されて おり，提案する出力電圧補償方式が入力側の制御に影響を 及ぼさないことが確認できる。

以上より，提案する制御手法を用いることで，発電機を マトリックスコンバータに接続した場合でもシステムを安 定に制御することが可能であり，かつ，電動機の駆動にも 対応できることが確認できた。

7. まとめ

本論文では，マトリックスコンバータに同期発電機と誘 
導電動機を接続した場合の動作特性について検討した。発 電機の同期リアクタンスによるシステムの不安定性を検証 し, 解決策として, 入力電流の制御に回転座標変換とダン ピング制御を組み合わせた安定化制御を提案し, 発電機側 の安定化と回転数の変動に対応した。加えて, 入力力率と 発電機の端子電圧, 出力電圧の関倸を明確化し, 電圧利用 率が最大となる最適入力力率制御を提案した。さらに, 発 電機の運転状況に対応して, 逆起電力を用いた出力電圧変 動補償法を提案した。

以上の提案方式を用いて, 発電機と電動機を接続したマ トリックスコンバータシステムによる実験を行い, 以下の 結果を得た。

（1）一般的な制御においてシステムは不安定となるが, 提案制御を用いることでシステムが安定に動作できること

(2) 誘導電動機 $1.5 \mathrm{~kW}$ 出力時に入力電流ひずみ率 $3.7 \%$, 出力電流ひずみ率 $1.7 \%$ の良好な入出力波形 ${ }^{(15)}$ が 得られること

（3）誘導電動機加減速実験により, 加減速時の発電機の 安定した制御と良好な誘導電動機駆動特性が得られること

（4）同期発電機加減速実験により，発電機の端子電圧 の変動が起こった場合でも出力電圧を一定に補償可能であ ること

以上より, 提案する制御法が発電機の制御と電動機の駆 動に有用であることを確認した。

な㧍, 本研究は平成 17 年度産業技術研究助成事業の支援 を受けており，関係各位に感謝の意を表します。

(平成 20 年 6 月 6 日受付, 平成 20 年 12 月 12 日再受付)

\section{文献}

(1) J. Itoh, H. Kodachi, A. Odaka, I. Sato, H. Ohguchi, and H. Umida: "A High Performance Control Method for the Matrix Converter Based on PWM generation of Virtual AC/DC/AC Conversion", JIASC IEEJ, pp.I-303-I-308 (2004) (in Japanese)

伊東淳一 - 小太刀博和 - 小高章弘 - 佐藤以久也 - 大口英樹 - 海田英俊： 「パルスパターンに着目した仮想 AC/DC/AC 変換方式によるマトリッ クスコンバータの高性能化」, 平 16 電学産業応用部大, pp.I-303-I-308 (2004)

(2) A. Odaka, I. Sato, H. Ohguchi, Y. Tamai, H. Mine, and J. Itoh: "A PAM Control Method for the Matrix Converter Based on Virtual AC/DC/AC Conversion Method", IEEJ Trans., Vol.126-D, No.9, pp.1185-1192 (2006-9) (in Japanese)

小高章弘·佐藤以久也·大口英樹·玉井康寛·美根宏則 $\cdot$ 伊東淳一 :「仮 想 AC/DC/AC 変換方式に基づいたマトリックスコンバータの PAM 制御法」, 電学論 D, 126, 9, pp.1185-1192 (2006-9)

(3) J. Oyama, X. Xia, T. Higuchi, K. Kuroki, E. Yamada, and T. Koga: "VVVF On-line Control of Matrix Converter", IEEJ Trans., Vol.116-D, No.6, pp.644-651 (1996-6) (in Japanese)

小山 純 · 夏 暁戒 ·樋口 剛 - 黒木恒二 · 山田英二 ·古賀高志： 「PWM サイクロコンバータの VVVF オンライン制御」, 電学論 D, 116, 6, pp.644-651 (1996-6)

(4) T. Takeshita and H. Shimada: "Matrix Converter Control Using Direct AC/AC Conversion Approach to Reduce Output Voltage Harmonics", IEEJ Trans., Vol.126-D, No.6, pp.778-787 (2006-6) (in Japanese) 竹下隆晴・島田大志：「出力電圧高調波を低減する $\mathrm{AC} / \mathrm{AC}$ 直接変
換方式マトリックスコンバータ制御」, 電学論 D, 126, 6, pp.778-787 (2006-6)

(5) Y. Tadano, S. Hamada, S. Urushibata, M. Nomura, Y. Sato, and M. Ishida: "A Space Vector Modulation Scheme for Matrix Converter that Gives Top Priority to the Improvement of the Output Control Performance", IEEJ Trans., Vol.128-D, No.5, pp.631-641 (2008-5) (in Japanese)

只野裕吾 · 濱田鎮教 - 漆畑正太 - 野村昌克 - 佐藤之彦 - 石田宗秋 : 「出力制御性能の向上に着目したマトリックスコンバー夕の空間べ クトル変調法」, 電学論 D, 128, 5, pp.631-641 (2008-5)

(6) T. Nunokawa and T. Takeshita: "Resonance Suppression Control on Complex Plane for Three-Phase to Three-Phase Matrix Converters", SPC-07-80, pp.33-38 (2007) (in Japanese)

布川智康・竹下隆晴 :「複素座標変換を用いた三相/三相マトリックス コンバータの共振抑制制御」, 半導体電力変換研究会, pp.33-38 (2007)

(7) I. Sato, J. Itoh, H. Ohguchi, A. Odaka, and H. Mine: "An Improvement Method of Matrix Converter Drives Under Input Voltage Disturbances", IPEC-Niigata, pp.546-551 (2005)

(8) H. Nikkhajoei and M. Reza Iravani: "A Matrix Converter Based MivroTurbine Distributed Generation System", IEEE Trans., Vol.20, No.3, pp.2182-2192 (2005)

(9) E. Wiechmann, P. Burgos, and J. Rodriguez: "Continuously MotorSynchronized Ride-Through Capability for Matrix-Converter AdjustableSpeed Drives", IEEE Trans., Vol.49, No.2, p.390 (2002)

(10) J. Lettl: "Matrix Converter Induction Motor Drive", EPE-PEMC, pp.787792 (2006)

(11) F. Blaabjerg, D. Casadei, C. Klumpner, and M. Matteini: "Comparison of Two Current Modulation Strategies for Matrix Converters Under Unbalanced Input Voltage Conditions", IEEE Trans., Vol.49, No.2, pp.289-296 (2002)

(12) P.W. Wheeler, J. Rodriguez, J.C. Clare, and L. Empringham: "Matrix Converters: A Technology Review", IEEE Trans. on Industry Electronics, Vol.49, No.2, pp.274-288 (2002)

(13) P.W. Wheeler, J.C. Clare, and P. Zanchetta: "A Three-Phase Utility Power Supply Based on the Matrix Converter", IAS, pp.1447-1451 (2004)

(14) J. Itoh, J. Toyosaki, and H. Ohsawa: "High performance V/f control method for PM Motor”, IEEJ Trans., Vol.122-D, No.3, pp.253-259 (2002-3) (in Japanese)

伊東淳一・豊崎次郎 ·大沢 博: 「永久磁石同期電動機の V/f 制御の 高性能化」, 電学論 D, 122, 3, pp.253-259 (2002-3)

(15) K. Kato and J. Itoh: "Development of a Novel Commutation Method which Drastically Suppresses Commutation Failure of a Matrix Converter", IEEJ Trans., Vol.127-D, No.8, pp.829-836 (2007-8) (in Japanese) 加藤康司・伊東淳一:「マトリックスコンバータの転流失敗を激減 する新しい転流方式の開発」, 電学論 D, 127, 8, pp.829-836 (2007-8)

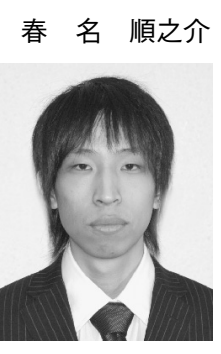

（学生員） 1983 年 7 月 6 日生。 2006 年 3 月長岡 技術科学大学卒業。2008 年 3 月同大学大学院工 学研究科修士課程電気電子情報工学専攻修了。同 年 4 月博士後期課程エネルギー・環境工学専攻に 進学。主に電力変換回路に関する研究に従事。

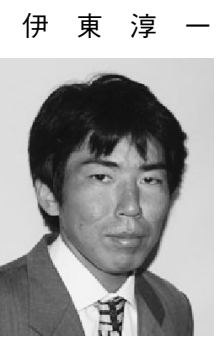

（正員） 1972 年生。1996 年 3 月長岡技術科学大 学大学院工学研究科修士課程修了。同年 4 月, 富 士電機 (株) 入社。2 004 年 4 月長岡技術科学大学 電気系准教授。現在に至る。主に電力变換回路, 電動機制御の研究に従事。博士（工学）（長岡技 術科学大学)。2007 年第 63 回電気学術振興賞進 歩賞受賞。IEEE 会員。 